\title{
Concentration of microbial populations from aquatic environments by Vortex Flow Filtration
}

\author{
Sunny C. Jiang, Jennifer M. Thurmond, Scott L. Pichard, John H. Paul*
}

Department of Marine Science, University of South Florida, 140 Seventh Avenue South, St. Petersburg, Florida 33701-5016, USA

\begin{abstract}
Vortex Flow Filtration was used to concentrate particulate DNA, chlorophyll a and bacteria from freshwater, estuarine, coastal and oligotrophic marine environments. A Membrex Benchmark System with either a $100 \mathrm{kD}$ or a $0.45 \mu \mathrm{m}$ filter and a large-scale Pacesetter System with a $100 \mathrm{kD}$ filter were used. The Benchmark System is ideal for processing $100 \mathrm{ml}$ to $50 \mathrm{l}$ of water, while the Pacesetter is designed for working with volumes from $20 \mathrm{l}$ up to hundreds of liters. The Benchmark System with a $100 \mathrm{kD}$ filter yielded an average recovery of $81.7,83.3$ and $80.5 \%$ respectively for particulate DNA, chlorophyll $a$ and bacteria. The efficiency of recovery with the Pacesetter System was $38.0,38.1$ and $43.6 \%$ respectively for particulate DNA, chlorophyll $a$, and bacteria. The filtration rate was $66.5 \pm 10 \mathrm{l} \mathrm{h}^{-1}$ for the Pacesetter and $7.8 \mathrm{l} \mathrm{h}^{-1}$ for the Benchmark System with the $100 \mathrm{kD}$ filters. Our results indicate that the Benchmark System is suitable for quantitive studies that require a high efficiency of recovery using small volumes of water, while the Pacesetter is more suited for qualitative studies that require concentrating microbial populations from large quantities of water for genetic and molecular phylogenetic studies.
\end{abstract}

\section{INTRODUCTION}

Recent molecular technologies for the study of the composition of marine microbial communities require efficient harvesting of large quantities of microbial biomass. Because of the naturally low bacterial abundances, ca $10^{5}$ cells $\mathrm{ml}^{-1}$ in oligotrophic and $10^{7}$ cells $\mathrm{ml}^{-1}$ in estuarine and freshwater environments (Jannasch \& Jones 1959, Watson et al. 1977, Kogure et al. 1979, Paul et al. 1985, 1986, 1987, 1989 , David \& Paul 1989), it is necessary to concentrate cells from large volumes (several liters to hundreds of liters) of water. Methods used previously to collect picoplankton for bulk analyses include direct filtration through cylindrical membrane filters (Somerville et al. 1989), vacuum filtration onto fluorocarbon-based filters (Fuhrman et al. 1988), tangential flow filtration (Barthel et al. 1989, Giovannoni et al. 1990) and hollow-fiber filtration (Sherr et al. 1987, Proctor \& Fuhrman 1990). Only relatively small volumes can be filtered by the first 2 methods. The tangential

\footnotetext{
- Addressee for correspondence

flow filtration system was first employed in the ocean sciences to concentrate picoplankton and nanoplankton by Barthel et al. (1989). Giovannoni et al. (1990a, b) used tangential flow filtration to concentrate up to $8000 \mathrm{l}$ of water. Cell recovery in the concentrated slurries was reported to be $37 \%$ by direct cell count (Giovannoni et al. 1990a, b). Hollow-fiber filtration enabled efficient concentration $(96 \%$ ) of natural bacterial populations from $4 \mathrm{l}$ of estuarine water (Sherr et al. 1987).

Vortex Flow Filtration (VFF) is a filtration technology based upon Taylor vortices (Taylor 1923). Taylor vortices are established in a vortex flow filtration device by rotation of a cylindrical filter inside a second cylinder (Fig. 1). The sample is fed under pressure between these 2 cylindrical surfaces, forcing fluids across the filter and into the inner cylinder for collection or out to waste. The vortices constantly keep the filter surface clean which prevents clogging and minimizes cell damage.

We have recently applied VFF to the concentration of viruses and dissolved DNA from marine environments (Paul et al. 1991). The efficiency of recovery was estimated to be $72.8 \%$ and $80.0 \%$ for viruses 


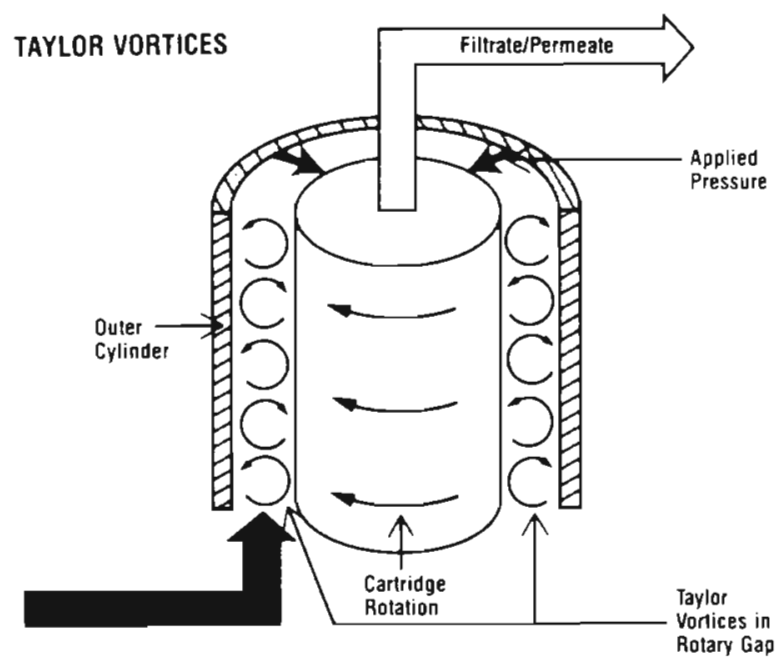

Fig. 1 Taylor vortices are created by rotating a cylinder at a critical velocity within a narrow annular gap. These vortices are pairs of counter-rotating 'rings' whose diameter is equivalent to the annular gap. This system dramatically reduces the problems of membrane fouling and concentration polar-

ization. (Reproduced by permission of Membrex, Inc.)

and dissolved DNA, respectively. This methodology was also used to concentrate pathogens and viruses for isolation from aquatic environments (Reynolds et al. 1991). Here we describe the use of VFF for collection of microbial populations from estuarine, coastal, oligotrophic and freshwater environments. This procedure has resulted in efficient recovery of autotrophic and heterotrophic microbial populations as indicated by bacterial direct counts, chlorophyll a and particulate DNA.

\section{MATERIALS AND METHODS}

Field sampling sites. Freshwater samples were collected from the Medard Reservoir, Valrico, and Lake Maggorie, St. Petersburg, Florida, USA. These are shallow eutrophic bodies of water influenced by agriculture and urban runoff, respectively. Estuarine surface water samples were taken from Tampa Bay at Bayboro Harbor, Hooker's Point and The Pier, St. Petersburg. During a research cruise aboard RV 'Cape Hatteras' (\#CH-12-90), water samples were taken in the Atlantic Ocean near Miami $\left(25^{\circ} 45.10^{\prime} \mathrm{N}\right.$, $80^{\circ}$ 05.14' W), in Northwest Providence Channel, Bahamas $\left(26^{\circ} 07.90^{\prime} \mathrm{N}, 78^{\circ} 32.50^{\prime} \mathrm{W}\right.$ ), in the subtropical North Atlantic Ocean at a depth of $1500 \mathrm{~m}$ $\left(25^{\circ} 46.90^{\prime} \mathrm{N}, 76^{\circ} 49.50^{\prime} \mathrm{W}\right)$ and Joulter's Cay, Bahamas $\left(25^{\circ} 19.07^{\prime} \mathrm{N}, 78^{\circ} 05.33^{\prime} \mathrm{W}\right)$. Water samples were taken with Niskin bottles on the cruises and with a dip bucket for Tampa Bay sampling.
VFF concentration of samples. A Benchmark rotary biofiltration unit (Membrex Inc., Garfield, NJ, USA) was used for VFF concentration of samples. The system was set up in the recirculation configuration as previously described (Paul et al. 1991) with either a $0.45 \mu \mathrm{m}$ or a $100 \mathrm{kD}$ filter. The filtration was performed at 9 to $10 \mathrm{psi}\left(4.7\right.$ to $\left.6.7 \times 10^{4} \mathrm{~Pa}\right)$ with a filter rotation speed of $2000 \mathrm{rpm}$ for a $200 \mathrm{~cm}^{2}$ filter or at 7 to $8 \mathrm{psi}$ $\left(4.7\right.$ to $\left.5.4 \times 10^{4} \mathrm{~Pa}\right)$ with a filter rotation speed of $1500 \mathrm{rpm}$ for a $400 \mathrm{~cm}^{2}$ filter. The sample was pumped in from the feed vessel in the recirculation mode until the feed vessel was empty. The concentrated, filtered water was termed the 'retentate', and the filtate was termed the 'permeate'. At this time the feed port was closed, an air pump was fitted to the retentate line, and the retentate volume reduced under positive air pressure to 15 to $50 \mathrm{ml}$.

A Pacesetter unit (Membrex, Inc.) with a $100 \mathrm{kD}$ filter was used for large-volume water samples (71.8 to 415.31 l). This system is based on the same design as the Benchmark but equipped with a $2300 \mathrm{~cm}^{2}$ filter (Fig. 2). The operation procedure of this system is the same as the Benchmark cxccpt that, whon the focd vessel was empty (Fig. 2), the retentate (reduced to a liter volume) was collected, and reconcentrated by the Benchmark System to 35 to $50 \mathrm{ml}$. The filtration rate of the Pacesetter and Benchmark Systems were 66.5 \pm 10 $\mathrm{l} \mathrm{h}^{-1}$ and $7.8 \mathrm{l} \mathrm{h}^{-1}$, respectively. Retentates were stored at $4^{\circ} \mathrm{C}$ after harvesting.

Recovery of particulate DNA, chlorophyll a and bacteria. Particulate DNA was determined by the Hoechst 33258 method (Paul et al. 1982). Chlorophyll a was analyzed by the method of Holm-Hansen \& Riemann (1978). Direct counts of bacteria were performed by DAPI epifluorescent microscopy as previously described (Paul 1982). The percent recovery in the retentate was calculated as: Retentate Recovery = $\left(C_{\mathrm{r}} \times V_{\mathrm{r}} / C_{1} \times V_{\mathrm{i}}\right) \times 100$, where $C_{\mathrm{r}}$ is the concentration of cells, chlorophyll $a$, or particulate DNA in the retentate, $V r$ is the volume of retentate, $C_{i}$ is the initial concentration and $V_{\mathrm{i}}$ is the initial volume. The percentage of material that passed through the filter was calculated as the concentration of material in the permeate divided by the initial (prefiltation) concentration multiplied by 100 .

\section{RESULTS}

\section{Concentration of bacteria}

The results of concentration of bacteria by VFF appear in Table 1. Five liters of the Bayboro Harbor sample was concentrated to $15 \mathrm{ml}$ by the Benchmark System with a $0.45 \mu \mathrm{m}$ filter with a recovery of $19.3 \%$. 


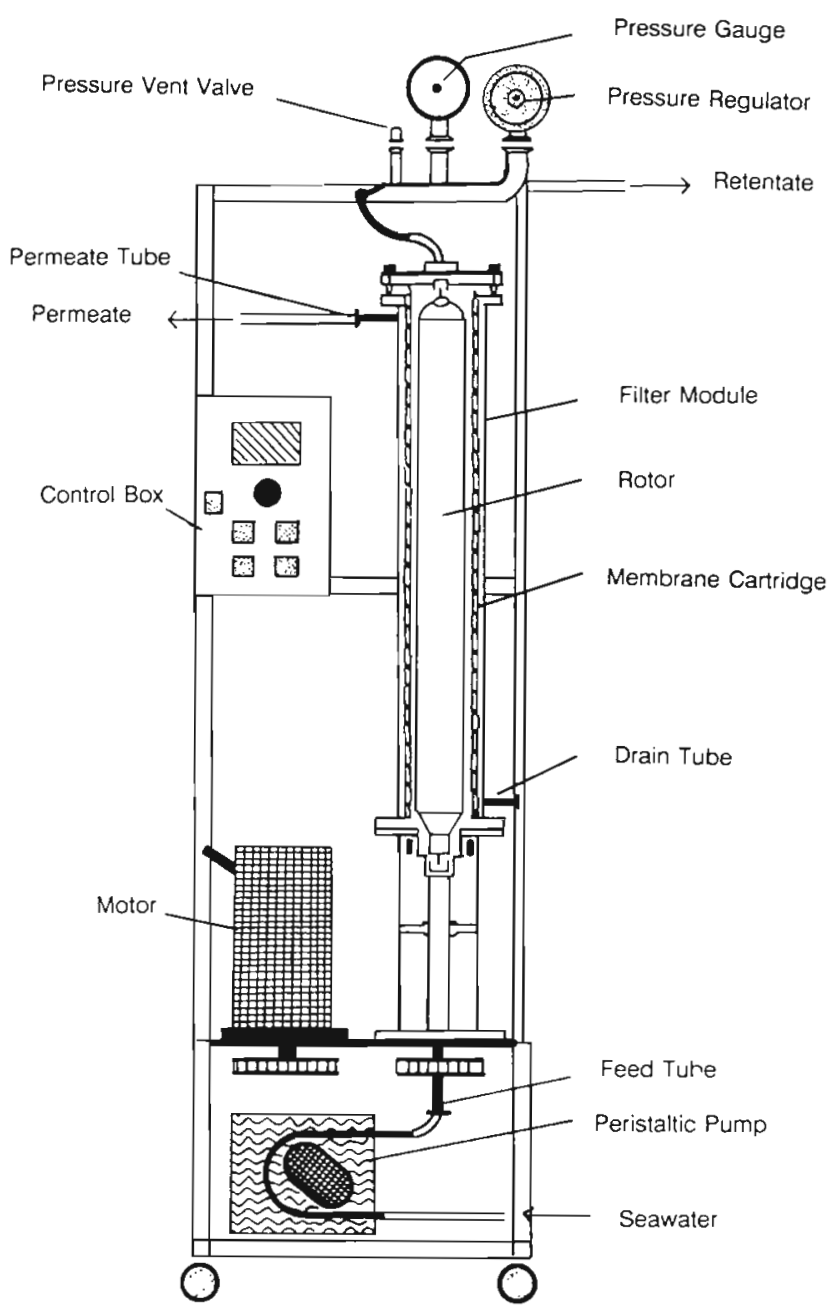

Fig. 2. Schematic diagram of a Pacesetter rotary biofiltration device. The filter module houses a single membrane cartridge with an area of $2.5 \mathrm{sq}$. $\mathrm{ft}\left(2300 \mathrm{~cm}^{2}\right)$. The sample is drawn in by a perstaltic pump in the feed line, and recirculated, concentrated material returns to the feed vessel by the retentate line. The filtrate is passed through the permeate line. The volume filtered is determined by a flowmeter on the permeate line

Only $9.05 \%$ of the original bacterial population was found in the permeate (see 'Discussion'). The Benchmark System with a $100 \mathrm{kD}$ filter was used to process nearshore and offshore oceanic water samples as well as freshwater samples from Lake Maggorie and the Medard Reservoir. The recoveries ranged from 54.8 to $105 \%(\overline{\mathrm{x}}=80.5 \pm 18.4 \%)$. Only 2 permeates from the nearshore samples were analyzed, and less than $0.41 \%$ of the bacteria passed the filter and was detected by direct counts in the permeate fraction. The lowest recovery of $54.8 \%$ occurred in the oligotrophic environment of the Northwest Providence Channel of the Bahamas. For the Pacesetter System equipped with a $100 \mathrm{kD}$ filter, recoveries ranged from 11.4 to $241 \%$ $(\bar{x}=43.5 \pm 30.9 \%$ not including the one of $241 \%$, see 'Discussion'). An oligotrophic water sample of $71.8 \mathrm{l}$ from the Northwest Providence Channel, Bahamas, was concentrated to $34 \mathrm{ml}$ with a recovery of $27.6 \%$. The lowest recovery $(11.4 \%)$ was obtained from a mesopelagic sample from the Atlantic Ocean $(1500 \mathrm{~m})$, which initially had $8.3 \times 10^{4}$ cells $\mathrm{ml}^{-1}$. The retentate contained $3.34 \times 10^{7}$ cells $\mathrm{ml}^{-1}$ for a concentration factor of 408 .

\section{Concentration of autotrophic populations: chlorophyll a}

The results of the concentration of autotrophic populations as indicated by recovery of chlorophyll a by VFF appear in Table 2. When a Bayboro Harbor water sample was concentrated by the Benchmark System with a $0.45 \mu \mathrm{m}$ filter, a $41 \%$ recovery was obtained. The retentate contained $1970 \mu \mathrm{g}$ chlorophyll a $\mathrm{l}^{-1} \mathrm{com}$ pared to $14.4 \mu \mathrm{g} \mathrm{l}^{-1}$ for the starting material. Less than $0.48 \%$ of the chlorophyll $a$ in the origin sample was detected in the permeate (see 'Discussion'). When a $100 \mathrm{kD}$ filter was used in the Benchmark System, recoveries ranged from 75 to $97.7 \%(\bar{x}=83.3 \pm 9.0 \%)$. In 3 of 8 experiments, chlorophyll a concentrations were analyzed in the permeates, and less than $2.8 \%$ of the chlorophyll $a$ in the original sample was found in this fraction. The Pacesetter System with a $100 \mathrm{kD}$ filter gave a recovery of $38.1 \%$. In this experiment, 1001 of water was concentrated to $58.0 \mathrm{ml}$ with a final concentration of $2167 \mu \mathrm{g}$ chlorophyll $a \mathrm{l}^{-1}$. Up to $63.6 \%$ of the chlorophyll $a$ in the original sample was found in the permeate.

\section{Concentration of microbial populations: particulate DNA}

The results of the concentration of particulate DNA by VFF appear in Table 3 . When the $0.45 \mu \mathrm{m}$ filter was employed, the particulate DNA from 5.0 l of seawater was concentrated to $15.0 \mathrm{ml}$, with an overall recovery of $22.6 \%$. A total of $36 \mu \mathrm{g}$ of DNA was obtained in the concentrate. Of the total particulate DNA, $27.4 \%$ was found in the permeate. Using a $100 \mathrm{kD}$ filter in this system the recoveries ranged from 66.8 to $96.1 \%$ ( $\bar{x}=$ $81.7 \pm 14.6 \%$ ). An average of only $3.2 \%$ of the total DNA content was detected in the permeates. The highest DNA yield was $436 \mu \mathrm{g}$ in $57 \mathrm{ml}$ of concentrate. The Pacesetter System was used to concentrate $100 \mathrm{l}$ of estuarine water to $58.0 \mathrm{ml}$ (a 1724-fold concentration) with a $38 \%$ recovery, yielding $1.2 \mathrm{mg}$ DNA. Of the total particulate DNA, $47.6 \%$ in the sample appeared in the permeate. 
Table 1. Concentration of aquatic bacteria by VFF

\begin{tabular}{|c|c|c|c|c|c|c|}
\hline $\begin{array}{l}\text { Sample \& date } \\
\text { of collection }\end{array}$ & $\begin{array}{l}\text { Initial } \\
\text { volume } \\
\text { (1) }\end{array}$ & $\begin{array}{c}\text { Initial } \\
\text { direct count } \\
\left(10^{6} \mathrm{ml}^{-1}\right)\end{array}$ & $\begin{array}{l}\text { Final } \\
\text { volume } \\
\text { (ml) }\end{array}$ & $\begin{array}{l}\text { Final } \\
\text { direct count } \\
\left(10^{6} \mathrm{ml}\right)\end{array}$ & $\begin{array}{c}\text { Recovery } \\
(\%)\end{array}$ & $\begin{array}{l}\text { Loss in per- } \\
\text { meate fraction } \\
(\%)\end{array}$ \\
\hline $\begin{array}{l}\text { Benchmark } 0.45 \mu \mathrm{m} \text { filter } \\
\text { Bayboro Harbor } \\
\text { 31 Jul } 1989\end{array}$ & 5.0 & $3.1 \pm 0.22$ & 15.0 & $199 \pm 20$ & 19.3 & 9.1 \\
\hline $\begin{array}{l}\text { Benchmark } 100 \text { kD filter } \\
\text { Lake Maggorie } \\
29 \text { Nov } 1989\end{array}$ & 4.0 & $5.8 \pm 0.07$ & 30.0 & $563 \pm 69$ & 72.7 & - \\
\hline $\begin{array}{l}\text { Medard Reservoir } \\
29 \text { Nov } 1989\end{array}$ & 4.0 & $10.1 \pm 1.6$ & 25.0 & $1163 \pm 144$ & 72.0 & - \\
\hline $\begin{array}{l}\text { Bayboro Harbor } \\
6 \text { Nov } 1989\end{array}$ & 2.0 & $3.4 \pm 0.4$ & 22.0 & $323 \pm 46$ & 105 & 0 \\
\hline $\begin{array}{l}\text { Hookers Point, Tampa Bay } \\
7 \text { Nov } 1990\end{array}$ & 20.0 & $5.1 \pm 1.1$ & 57.0 & $1660 \pm 243$ & 93.7 & 0.41 \\
\hline $\begin{array}{l}\text { St.Petersburg Pier } \\
28 \text { Nov } 1990\end{array}$ & 5.0 & $3.7 \pm 0.24$ & 46.0 & $387 \pm 45$ & 96.2 & - \\
\hline $\begin{array}{l}\text { St.Petersburg Pier } \\
16 \text { Jan } 1991\end{array}$ & 5.0 & $2.6 \pm 0.08$ & 47.0 & $272 \pm 13$ & 98.3 & - \\
\hline $\begin{array}{l}\text { St.Petersburg Pier } \\
31 \text { Feb } 1991\end{array}$ & 5.0 & $2.2 \pm 0.06$ & 47.0 & $144 \pm 9.6$ & 61.5 & - \\
\hline $\begin{array}{l}\text { St.Petersburg Pier } \\
27 \text { Mar } 1991\end{array}$ & 5.0 & $2.3 \pm 0.24$ & 37.0 & $204.0 \pm 58.1$ & 65.6 & - \\
\hline $\begin{array}{l}\text { St.Petersburg Pier } \\
\text { 14 May } 1991\end{array}$ & 5.0 & $3.2 \pm 0.12$ & 51.0 & $318 \pm 15.7$ & 101 & - \\
\hline $\begin{array}{l}\text { N.W. Providence Channel, Bahamas } \\
31 \text { Aug } 1990\end{array}$ & 25.0 & $0.42 \pm 0.14$ & 36.4 & $158 \pm 9.3$ & 54.8 & - \\
\hline $\begin{array}{l}\text { Mangrove lagoon, Joulter's Cay, Bahamas } \\
11 \text { Sep } 1990\end{array}$ & 10.0 & $1.4 \pm 0.31$ & 50.0 & $180 \pm 16$ & 64.3 & - \\
\hline $\begin{array}{l}\text { Pacesetter } 100 \text { kD filter } \\
\text { Hookers Point, Tampa Bay } \\
7 \text { Nov } 1990\end{array}$ & 100 & $5.1 \pm 1.1$ & 58.0 & $4621 \pm 234$ & 52.6 & - \\
\hline $\begin{array}{l}\text { Atlantic Ocean, Miami Beach } \\
30 \text { Aug } 1990\end{array}$ & 306 & $1.3 \pm 0.28$ & 50.0 & $6540 \pm 140$ & 82.2 & - \\
\hline $\begin{array}{l}\text { Joulter's Cay, Bahamas } \\
3 \text { Sep } 1990\end{array}$ & 415.3 & $0.46 \pm 0.035$ & 50.0 & $9200 \pm 1980$ & 241 & - \\
\hline $\begin{array}{l}\text { N.W. Providence Channel, Bahamas } \\
31 \text { Aug } 1990\end{array}$ & 71.8 & $0.42 \pm 0.14$ & 34.0 & $245 \pm 102$ & 27.6 & - \\
\hline $\begin{array}{l}\text { Atlantic Ocean, } 1500 \mathrm{~m} \text { depth } \\
1 \text { Sep } 1990\end{array}$ & 192.8 & $0.083 \pm 0.022$ & 53.6 & $33.9 \pm 6.1$ & 11.4 & - \\
\hline
\end{tabular}

\section{DISCUSSION}

The VFF Benchmark System with a $100 \mathrm{kD}$ filter has been shown to be an efficient and rapid means of concentrating autotrophic and heterotrophic microbial poulations from aquatic environments. The overall efficiencies of harvesting particulate DNA, chlorophyll $a$ and bacteria were $81.7,83.8$ and $80.5 \%$ respectively. The efficiency of the Pacesetter System was about half of that of the Benchmark System 138.038 .1 and $43.6 \%$ for particulate DNA, chlorophyll a and bacteria, respectively). However, the water sample was processed 8.5 times faster by the Pacesetter System than the Benchmark System (66.5 $\mathrm{l} \mathrm{h}^{-1}$ and $7.8 \mathrm{l} \mathrm{h}^{-1}$ for Pacesetter and Benchmark System, respectively, with $100 \mathrm{kD}$ filters). It is therefore practical to harvest several hundred liters of seawater with the latter. The Benchmark System is preferred when samples are less than 50 l. Its small size, light weight, and general mobility make it easier for processing samples near field sites and on cruises. 
Table 2. Concentration of chlorophyll a by VFF

\begin{tabular}{|c|c|c|c|c|c|c|}
\hline $\begin{array}{l}\text { Sample \& date } \\
\text { of collection }\end{array}$ & $\begin{array}{c}\text { Initial } \\
\text { volume } \\
\text { (1) }\end{array}$ & $\begin{array}{l}\text { Initial } \\
\text { conc. } \\
\left(\mu \mathrm{g}^{-1}\right)\end{array}$ & $\begin{array}{l}\text { Final } \\
\text { volume } \\
\text { (mi) }\end{array}$ & $\begin{array}{c}\text { Final } \\
\text { conc. } \\
\left(\mu g l^{-1}\right)\end{array}$ & $\begin{array}{c}\text { Recovery } \\
(\%)\end{array}$ & $\begin{array}{c}\text { Loss in per- } \\
\text { meate fraction } \\
(\%)\end{array}$ \\
\hline $\begin{array}{l}\text { Benchmark } 0.45 \mu \mathrm{m} \text { filter } \\
\text { Bayboro Harbor }\end{array}$ & & & & & & \\
\hline 31 Jul 1989 & 5.0 & $14.4 \pm 1.21$ & 15.0 & $1970 \pm 50$ & 41 & 0.48 \\
\hline $\begin{array}{l}\text { Benchmark } 100 \text { kD filter } \\
\text { Bayboro Harbor }\end{array}$ & & & & & & \\
\hline 23 Oct 1989 & 2.0 & $4.5 \pm 0.16$ & 13.5 & $500 \pm 34$ & 75 & 2.8 \\
\hline $\begin{array}{l}\text { Bayboro Harbor } \\
6 \text { Nov } 1989\end{array}$ & 2.0 & $3.0 \pm 0.15$ & 22.0 & $233 \pm 35$ & 85.4 & 0.3 \\
\hline $\begin{array}{l}\text { Hookers Point, Tampa Bay } \\
7 \text { Nov } 1989\end{array}$ & 20.0 & $3.3 \pm 0.28$ & 57.0 & $921 \pm 20$ & 80.0 & 0 \\
\hline $\begin{array}{l}\text { St.Petersburg Pier } \\
28 \text { Nov } 1990\end{array}$ & 5.0 & $1.58 \pm 0.1$ & 46.0 & $129 \pm 16.3$ & 75.1 & - \\
\hline $\begin{array}{l}\text { St.Petersburg Pier } \\
16 \text { Jan } 1991\end{array}$ & 5.0 & $3.82 \pm 0.1$ & 47.0 & $397 \pm 97.6$ & 97.7 & - \\
\hline $\begin{array}{l}\text { St.Petersburg Pier } \\
13 \text { Feb } 1991\end{array}$ & 5.0 & $4.25 \pm 0.69$ & 47.0 & $405 \pm 24.5$ & 89.6 & - \\
\hline $\begin{array}{l}\text { St.Petersburg Pier } \\
27 \text { Mar } 1991\end{array}$ & 5.0 & $1.43 \pm 0.3$ & 37.0 & $180 \pm 6.8$ & 93.1 & - \\
\hline $\begin{array}{l}\text { St.Petersburg Pier } \\
14 \text { May } 1991\end{array}$ & 5.0 & $3.81 \pm 0.18$ & 51.0 & $300 \pm 17.6$ & 80.3 & - \\
\hline $\begin{array}{l}\text { Pacesetter } 100 \text { kD filter } \\
\text { Hookers Point, Tampa Bay } \\
7 \text { Nov } 1990\end{array}$ & 100.0 & $3.3 \pm 0.28$ & 58.0 & $2167 \pm 53$ & 38.1 & 63.6 \\
\hline
\end{tabular}

The efficiency of recovery appeared related to the initial cell concentration of the sample. The efficiency was lower in the mesopelagic and oligotrophic environments, where the initial cell concentration was low. This may because a constant number of the cells always attached to the filter and/or cylinder chamber. The lower the initial cell concentration is, the higher this percentage of the cells becomes, and the lower the recovery is.

We are confident that the $100 \mathrm{kD}$ filter equally

Table 3. Concentration of microbial populations by VFF: particulate DNA

\begin{tabular}{|c|c|c|c|c|c|c|}
\hline $\begin{array}{l}\text { Sample \& date } \\
\text { of collection }\end{array}$ & $\begin{array}{c}\text { Initial } \\
\text { volume } \\
\text { (1) }\end{array}$ & $\begin{array}{l}\text { Initial } \\
\text { conc. } \\
\left(\mu g L^{-1}\right)\end{array}$ & $\begin{array}{c}\text { Final } \\
\text { volume } \\
\text { (ml) }\end{array}$ & $\begin{array}{c}\text { Final } \\
\text { conc } \\
\left(\mu \mathrm{gl}^{-1}\right)\end{array}$ & $\begin{array}{c}\text { Recovery } \\
(\%)\end{array}$ & $\begin{array}{l}\text { Loss in per- } \\
\text { meate fraction } \\
(\%)\end{array}$ \\
\hline $\begin{array}{l}\text { Benchmark } 0.45 \mu \mathrm{m} \text { filter } \\
\text { Bayboro Harbor }\end{array}$ & & & & & & \\
\hline 31 Jul 1989 & 5.0 & $33.1 \pm 0.9$ & 15.0 & $2490 \pm 190$ & 22.6 & 24.7 \\
\hline $\begin{array}{l}\text { Benchmark } 100 \mathrm{kD} \text { filter } \\
\text { Bayboro Harbor }\end{array}$ & & & & & & \\
\hline 23 Oct 1989 & 2.0 & $43.9 \pm 8.2$ & 13.5 & $5353 \pm 687$ & 82.3 & 1.8 \\
\hline $\begin{array}{l}\text { Bayboro Harbor } \\
6 \text { Nov } 1989\end{array}$ & 2.0 & $41.7 \pm 6.8$ & 22.0 & $3645 \pm 310$ & 96.2 & 7.8 \\
\hline $\begin{array}{l}\text { Hookers Point, Tampa Bay } \\
7 \text { Nov } 1990\end{array}$ & 20.0 & $32.6 \pm 3.8$ & 57.0 & $7644 \pm 610$ & 66.8 & 0 \\
\hline $\begin{array}{l}\text { Pacesetter } 100 \mathrm{kD} \text { filter } \\
\text { Hookers Point, Tampa Bay }\end{array}$ & 1000 & $326+38$ & 580 & $21370+3200$ & 380 & 476 \\
\hline
\end{tabular}


concentrates small and large cells. Our previous work on concentration of T2 phage (80 to $110 \mathrm{~nm}$; Freifelder 1987) with a $100 \mathrm{kD}$ filter using the Benchmark system yielded a recovery of $72.8 \%$ (Paul et al. 1991). If the $100 \mathrm{kD}$ filter efficiently harvested viruses, we believe it will also efficiently harvest bacterioplankton and phytoplankton, even the smallest forms.

The loss detected in the permeate may reflect leakage (mixing of retentate and permeate due to seal problem between 2 chambers), or cells passing through the membrane. Like most other filters, this membrane filter may contain a range of pore sizes. Thus a percentage of the greater than $100 \mathrm{kD}$ fraction may be able to pass though the membrane. This may also explain the reason why with the $100 \mathrm{kD}$ filter Pacesetter system achieved only about half of the efficiency of the Benchmark System. The Pacesetter is apparently designed to process samples with much higher cell concentrations than found in oligotrophic ocean waters. The manufacturer claims $>99 \%$ recovery when a saturated culture of Escherichia coli was concentrated by a Pacesetter System with a $100 \mathrm{kD}$ filter (Membrex, Inc. DF 106).

The $0.45 \mu \mathrm{m}$ filter was used in our Benchmark System only once in this study. Because of its low efficiency, we thought it was not suitable to concentrate microbial populations from aquatic environments. The total recovery (permeate and retentate) was $28.4 \%$ for bacteria, $41.5 \%$ for chlorophyll $a$, and $47.3 \%$ for particulate DNA. Because the filter appeared brown after use, we suspect that the remaining half of the microbial population was stuck on the filter surface with this filter type.

When the Pacesetter was used to concentrate 415.31 of water from Joulter's Cay, recovery was $241 \%$, indicating that more cells were found in the retentate than in the starting material. The concentration procedure took about $7.3 \mathrm{~h}$, and it is possible that the cells might have multiplied inside the Pacesetter cylinder chamber during the concentration period. This may be a problem with long-term concentration of unfixed samples by ultrafiltration. Bringing large quantities of cells into contact with high molecular weight nutrients can result in cell population growth.

For most experiments, the total biomass in the permeate and retentate was lower than initial concentration ( $\bar{x}=77.2 \%)$. This might be because some of the cells were adsorbed on the filter, cylinder wall or feed vessel, or that cells were lysed by the process. All filtration techniques share the drawback that they potentially cause cell lysis. According to the manufacturer, VFF yields high cell recoveries, even for fragile mammalian cells. A recovery of $93 \%$ was reported for mammalian cells concentrated by $100 \mathrm{kD}$ filter at $2000 \mathrm{rpm}$ (Membrex, Inc. DF 109, DF 111). We would expect bacterial populations to be more resistant to breakage than mammalian cells.

VFF is a new filtration technology for the concentration of aquatic microbial populations. Our work demonstrates the feasibility of harvesting large quantities of naturally occurring picoplankton by VFF. It may be applied in the phylogenetic study of unculturable marine picoplankton, pigment properties of phytoplankton populations, and lipids of aquatic microbial populations. VFF is not only able to concentrate picoplankton, but it also has been used to collect viruses and dissolved DNA from aquatic environments (Paul et al. 1991). Additionally, bacteriophages have been isolated from VFF retentates of seawater samples. This technology may also be applicable to the detection and quantitation of pathogenic viruses and other microbial pathogens from estuarine waters.

\section{LITERATURE CITED}

Barthel, K. G., Schneider, G., Gradinger, R., Lenz, J. (1989). Concentration of live pico- and nanoplankton by means of tangential flow tiltration. J. Plankton Res. 11: 1213-1221

David, A. W., Paul, J. H. (1989). Enumeration and sizing of aquatic bacteria by use of a silicon-intensified target camera linked-image analysis system. J. microbiol. Meth. 9: $257-266$

Freifelder, D. (1987). Molecular biology. Jones \& Bartlett Publications, Inc., Boston

Fuhrman, J. A., Comeau, D. E., Hagström, A., Chan, A. M. (1988). Extraction from natural planktonic microorganisms of DNA suitable for molecular biological studies. Appl. environ. Microbiol. 54: 1426-1429

Giovannoni, S. J., Britschgi, T. B., Moyer, C. L., Field, L. G. (1990a). Genetic diversity in Sargasso Sea bacterioplankton. Nature, Lond. 345: 60-63

Giovannoni, S. J., DeLong, E. F., Schmidt, I M., Pace, N. R. (1990b). Tangential flow filtration and preliminary phylogenetic analysis of marine picoplankton. Appl. environ. Microbiol. 56: 2572-2575

Holm-Hansen, O., Riemann, B. (1978). Chlorophyll a determination: improvements in methodology. Oikos 30 : $438-448$.

Jannasch, H. W., Jones, G. E. (1959). Bacterial populations in seawater as determined by different methods of enumeration. Limnol. Oceanogr. 4: 128-139

Kogure, K., Simidu, U., Taga, N. (1979). A tentative direct microscopic method for counting living marine bacteria. Can. J. Microbiol. 25: 415-420

Membrex, Inc. Bacterial cell harvesting: Vortex Flow Filtration vs Tangential Flow Filtration Systems. Pacesetter notes. DF 106. Garfield, NJ

Membrex, Inc. IgM clarification and concentration with high throughput and product recovery. Pacesetter notes. DF 109. Garfield, NJ

Membrex, Inc. Rapid clarification of $1 \mathrm{~L}-2$ from mammalian cells with high product recovery and high cell viability. Pacesetter notes. DF 111. Garfield, NJ

Paul, J. H. (1982). Use of Hoechst dyes 33258 and 33342 for enumeration of attached and planktonic bacteria. Appl. environ. Microbiol. 43: 939-944 
Paul, J. H., Myers, B. (1982). Fluorometric determination of DNA in aquatic microorganisms by use of Hoechst 33258. Appl. environ. Microbiol. 43: 1393-1399

Paul, J. H., DeFlaun, M. F., Jeffrey, W. H. (1986). Elevated levels of microbial activity in the coral surface microlayer. Mar. Ecol. Prog. Ser. 33: 29-40

Paul, J. H., Jeffery, W. H., DeFlaun, M. F. (1985). Particulate DNA in subtropical oceanic and estuarine environments. Mar. Biol. 90: 95-101

Paul, J. H., Jeffery, W. H., DeFlaun, M. F. (1987). Dynamics of extracellular DNA in the marine environment. Appl. environ. Microbiol. 53: 170-179

Paul, J. H., Jeffery, W. H., David, A. W., DeFlaun, M. F. Cazares, L. H. (1989). Turnover of extracellular DNA in eutrophic and oligotrophic freshwater environments of southwest Florida. Appl. environ. Microbiol. 55: $1823-1828$

Paul, J. H., Jiang, S. C., Rose, J. B. (1991). Concentration of viruses and dissolved DNA from aquatic environments by Vortex Flow Filtration. Appl. environ. Microbiol. 57: $2197-2204$

Reynolds, K. A., Jiang, C., Rose, J. B. (1991). The isolation and quantification of bacteriophage from the marine environ-

This article was presented by S. Y. Newell, Sapelo Island, Georgia, USA ment. In: Abstracts of the 91st General Meeting of the American Society for Microbiology, Abstract Q-121. American Society for Microbiology, Washington, D.C., p. 296

Proctor, L. M., Fuhrman, J. A. (1990). Viral mortality of marine bacteria and cyanobacteria. Nature, Lond. 343: 60-62

Sherr, B. F., Sherr, E. B., Fallon, R. D. (1987). Use of monodispersed, fluorescently labeled bacteria to estimate in situ protozoan bacterivory. Appl. environ. Microbiol. 53: 958-965

Somerville, C. C., Knight, I. T., Straube, W. L., Colwell, R. R. (1989). Simple, rapid method for direct isolation of nucleic acids from aquatic environment. Appl. environ. Microbiol. 55: $548-554$

Taylor, G. I. (1923). Stability of viscous liquid contained between two rotating cylinders. Phil. Trans. R. Soc. 223: $289-343$

Ward, D. M., Weller, R., Bateson, M. M. (1990). 16s rRNA sequences reveal numerous uncultured microorganisms in a natural community. Nature, Lond. 345: 63-65

Watson, S. W., Novitsky, T. J., Quinby, H. L., Valois, F. W. (1977). Determination of bacterial number and biomass in the marine environment. Appl, environ. Microbiol. 33: $940-946$

Manuscript first received: October 1991

Revised version accepted: January 9,1992 